\title{
Law and Ethics according to Nature
}

\author{
Valerio Tavormina \\ Former Full Professor of Law at the Catholic University in Milan, Milan, Italy \\ Email: valerio.tavormina@tavormina-balbis.it
}

How to cite this paper: Tavormina, V. (2019). Law and Ethics according to Nature. Beijing Law Review, 10, 1197-1202. https://doi.org/10.4236/blr.2019.105063

Received: September 27, 2019

Accepted: October 29, 2019

Published: November 1, 2019

Copyright $\odot 2019$ by author(s) and Scientific Research Publishing Inc. This work is licensed under the Creative Commons Attribution International License (CC BY 4.0).

http://creativecommons.org/licenses/by/4.0/

\begin{abstract}
Aim of the research is to identify the legal and ethical order most in line with a notion of nature understood in an empirical sense and to delimit its subjects. The sole available method can therefore be the logical-deductive one applied to the perceptible facts.
\end{abstract}

\section{Keywords}

Nonaggression Principle (NAP), Duties, Rights, Freedoms, Free Will, Normative Order

\section{Introduction}

Since content and foundation of a natural order (both juridical and ethical) are highly controversial, it seemed appropriate to verify whether the same can be deduced from the less controversial notion of nature in the sense of the whole empirically observable phenomena.

\section{Every Normative System Consists Exclusively of Duties of Behavior}

All agree that precepts and sanctions (although described by scholars in very different forms) are part of every legal or ethical system, although not everyone agrees on whether these systems consist only of precepts and sanctions or not (in this latter sense, for example, the minority institutionalist and neo-institutionalist doctrines ${ }^{1}$ ). And sanctions may even be represented just by a negative assessment of behaviors that do not conform to the precepts, which is rare in positive legal systems and instead frequent in ethical systems ${ }^{2}$.

${ }^{1}$ Buried, the institutionalist doctrines, by Kelsen and Bobbio (to name only the most authoritative), with shreds exhumed by the neo-institutionalist ones in the context of digressions with completely different contents: for bibliography (alone) refer to Tanzi, 2004; Pallante, 2008.

${ }^{2}$ In addition to the sanctions proper to an ethical-religious order, it may well be hypothesized, it seems to me, another ethical system in which the non-compliance of one of its precepts is followed, for example, from the exclusion of third party obligations advantageous for the non-compliant. 
In contrast to positive legal and ethical systems, that is to those set by some authority, but sometimes also to their justification, other "natural" systems have always been invoked or delineated, described by their assertors or creators as implicated by "nature" in itself or by nature of man, be the one or the other object of God's creation or not (see for example Murphy, 2011; Miller, 2008).

Even the libertarian stance we intend to take here, based on the Nonaggression Principle or NAP and described in terms of the property of each one on his own body and on whatever else he appropriated of (Long, 2008), is presented for example by Rothbard and Hoppe as corresponding to the nature of the human being, in the sense of his intrinsic characteristics: ability to think, feel, evaluate and act for (Rothbard, 1978: p. 30, 32, 33); ability to argue for Hoppe (1987: p. 157 fn. 118).

The related assumptions, all worthy of consideration even in the contents (subject to verification of their internal consistency ${ }^{3}$ ), lack however clarity in the enunciation of said contents also from the point of view of their type which is of interest here. In fact, as already illustrated elsewhere (Tavormina, 2003, 1ff.; Tavormina 2013, 48 f., $66 \mathrm{ff}$.), the bricks of every normative system (legal or ethical, positive or natural) are the duties of behavior (prohibitions included) and not (subjective) rights or liberties. The latter are only beneficial effects (which for certain duties may also be lacking in the positive legal systems) for third parties of the fulfillment of said duties.

Thus, while it may be very difficult for example to determine which is the most "natural" between the right to pursuit of happiness (of which the United States Declaration of Independence speaks) and the right to a "life project" much easier to operate the comparison if you first identify the individuals subject to and the content of the duties, the fulfillment of which entails for all others (or at least some of them) a right to happiness or to a "life project".

\section{The Less Duties, the More Natural Behaviors}

Taken as given in nature also all the possible intentional behaviors (the praxeological axiom laid down by Mises 1922, 94, 96 ff., and subsequently made its own among others by Rothbard, 1957, $108 \mathrm{f}$. and Hoppe, 1995, $22 \mathrm{ff}$.), it follows that the normative system most compliant with nature is the one that poses fewer duties, because it imposes the least number of modifications to what in fact can happen, that is, it reduces the situations of incompatibility between possible and due behaviors and, with said situations, the field of that conditioning factor of possible behaviors (additional to the scarcity of the means) represented precisely from their legal or ethical reprehensibility; that is, it allows the maximum possi${ }^{3}$ Starting from the old and recurring syncretism between natural and positive law, as a progressive adaptation of the former to the multiple cases of species (still upheld, for example, in the footsteps of Leoni, 1961, from Lottieri, 2009), which actually seems to me to be alternatively translatable without residues 1) into the deductive activity from rules set forth ex ante (which may and should always be the case for interpretation: Rödig 1973, 163 ss.) or 2) into the application of unspoken and ex post pretended preexisting deviations or (iii) in modifications (however justified) of the original rules. ${ }^{4}$ To use two figures mentioned by Mack, 2008: p. 245. 
ble freedom to act, which is at the same time economic freedom (action and economy coincide, since action unfailingly involves human body i.e. scarce means ${ }^{5}$ ).

Therefore, between the right to pursuit of happiness and the right to a "life project", the most "natural" will be that one which will appear as an advantageous reflection of a lower number of duties (even if such an examination does not have many chances of success with such empty formulas).

More generally, as inferable already from Democritus ${ }^{6}$, it seems to me that the minimum extension of duties is achieved by a system which limits itself to prohibiting anyone from impeding the actions (including, of course, omissions) of anyone else; that is (which is the same) to impede anyone else freely using his body; and that

1) whether this impediment is intended by the one who acts;

2) or if instead (although not intended) it is a consequence of his action, this latter representing what jurists call "proximate cause"; to use a more incisive (even if less precise) formula, a system limited to the Nonaggression Principle or NAP, in the sense of prohibition of significant (always to minimize the duties of behavior $^{7}$ ) physical invasion of the others' sphere, except for the consent of the interested party which does not count as an exception to the principle, but (in the exact limits in which it is given) as free use of the body of the interested party.

\section{The Minimum Conceivable Amount of Duties}

Excluding from said prohibition even only a part of the behaviors sub 2a), even if limitedly to relationships with a more or less extensive class of individuals 8 , would obviously not be possible without renouncing, in whole or in part, a regulatory model. This would, it is true, determine perfect correspondence - partially, at least - with the state of nature'; but this correspondence would inevitably be destined to disappear because, as history teaches us, a situation in which a certain, not small part of human interaction remains entrusted to physical force (or the threat of its application) leads to the establishment of legal (not obviously ethical) systems which, like those currently in force, are largely the result of ever-changing, much greater coercion than the simple $\mathrm{NAP}^{10}$.

\footnotetext{
${ }^{5}$ Hoppe 1987, 19: "one's body is indeed the prototype of a scarce good" (emphasis in original).

${ }^{6}$ In Diels 1903: p. 449, 55 B, fragment 246: "if no one were to harm others, the laws would have nothing against everyone living to his liking".

${ }^{7}$ The remark that this requirement renders the norm imprecise and therefore contributes to removing clarity and unequivocity from the libertarian system (Friedman, 1989: p. 86 and 90) applies to any regulatory system, not by chance always in need of interpretation (Rödig, 1973, loc. cit.).

${ }^{8}$ Slaves, serfs etc.

${ }^{9} \mathrm{~A}$ prohibition against resisting any compulsion would not be distinguished from its absence, because it can also be applied to any restorative compulsion.

${ }^{10}$ It can therefore be said that the origin, although not the content, of the existing legal systems is the most "natural" one. And in the face of this paradox, presented to him by Socrates, Callicles retracted, in Plato's Gorgias, his initial statement that the only right according to nature is that of force: Pievatolo, 2010, 483a-d, 489c-490a.
} 
Excluding instead from the NAP, in whole or in part, the behaviors sub $2 \mathrm{~b}$ ), even if it does not make the resulting system lose its sense, however it allows invasions of the sphere of the affected individual, without this being justified by the slightest difference with respect to the situation of the victim of a targeted action.

Compared to this minimal extension of a "natural" system, a greater extension of the duties of behavior cannot be defined likewise "natural", because it aims to prevent the obliged to behave "naturally", without this being justified by allowing others too to behave just as "naturally". And this occurs or can also occur in the most libertarian (or anarchist, as the author prefers) version of a supportive society (or left-oriented, as the author prefers), even if only by limiting the freedom of behavior through the principles of correctness, etc., excluding behavior dictated by animosity, limiting to chattels and personal possessions the fair acquisition through appropriation non-invasive of the sphere of others, etc. (Chartier 2013: p. 29, 49 ff., 86, 88, etc.).

In light of the foregoing considerations, legal and ethical, natural regulations come to assume a very precise and identical content: which obviously implies the superfluity of a natural ethic, as it is wholly absorbed by the natural legal order.

\section{Humans Only and Not Animals (Even the Ones Which Behave Intentionally) Have Duties or Rights}

It is now necessary to integrate the analysis with the boundaries of intentional behaviors and of interested subjects.

Since the regulatory model of the NAP, presented here as the most "natural", is articulated in the imposition on anyone of the prohibition to prevent the actions (and omissions) of anyone else, of which prohibition the ownership of each beneficiary on his own body is mere reflection (which includes, without exception, all the other situations normally labeled as rights and freedoms ${ }^{11}$ ), holder of all rights or freedoms can evidently only be the person to whom a reciprocal prohibition can be imposed. Otherwise the foundation of every subjective right or freedom should be found elsewhere; the subjects of the prohibition that founded said rights or liberties would have no correlative right or liberty; the same holder exempted from the ban could not invoke it against third parties who are in the same conditions as his, because they are also exempted ${ }^{12}$.

And then, within a regulatory "natural" framework, it is necessary to exclude from the obliged and entitled individuals, among the subjects to which recognizable intentional behaviors (as such subjected to economic analysis) have been attributed, the animals to which such recognizable intentional behaviors are ascribable, in order to keep them in the more traditional sphere of the objects of

${ }^{11}$ If no behavior that is not in turn impeding the behavior of others must be prevented, nothing else is needed to found any freedom and any possession of what was originally acquired without impeding the behavior of others.

${ }^{12}$ Rothbard 1982: p. 156: "it is more than a joke to point out that animals, after all, do not respect the 'rights' of other animals" (emphasis in original). 
the normatively considered action (Rothbard, 1982, $155 \mathrm{ff}$.): they cannot be burdened with the prohibition to impede the actions (and omissions) of any other animal or human being, because they have no free will or, in any case, no sense of responsibility in the Hayekian meaning of the term (Hayek 1960, $73 \mathrm{ff}^{13}$ ); nor consequently are they entitled to have the ban imposed on other animals and people, as foundation of their own rights and freedoms, since it would be inconceivable for the animals and without consideration for people.

Therefore, the current assumption of the existence, within the ambit of a "natural" order, of rights pertaining to animals or even to all sentient beings, which could not be considered mere objects belonging to others (Chartier, 2013, $93 \mathrm{ff} ., 315 \mathrm{ff}$.), represents just an expression of good feelings and a program of free behavior only in the sphere of those who prefigure them.

The argument is obviously different for babies and children, but only because they are destined to become human beings (Rothbard, 1982: p. 157).

\section{Conclusion}

NAP only for humans is all that is needed to have a complete legal and ethical system according to nature.

\section{Conflicts of Interest}

The author declares no conflicts of interest regarding the publication of this paper.

\section{References}

Chartier, G. (2013). Anarchy and Legal Order. New York: Cambridge University Press. https://doi.org/10.1017/CBO9781139424899

Diels, H. (1903). Die Fragmente der Vorsokratiker. Berlin: Weidmannsche Buchhandlung.

Friedman, D. D. (1989). The Machinery of Freedom (2nd ed.). Chicago, IL: Open Court.

Hayek, F. A. ([1960] 1978). The Constitution of Liberty. Chicago, IL: The University of Chicago Press.

Hoppe, H. H. ([1987] 2010). A Theory of Socialism and Capitalism. Auburn, AL: LvMI.

Hoppe, H. H. (1995). Praxeology and Economic Science. In Economic Science and the Austrian Method (pp. 7-48). Auburn, AL: LvMI.

Leoni, B. (1961). Freedom and the Law. Los Angeles, CA: Nash Publishing.

Long, R. (2008). Nonaggression Axiom. In R. Hamowy (Ed.), The Encyclopedia of Libertarianism (pp. 357-360). Los Angeles, CA: SAGE Publications.

Lottieri, C. (2009). Classical Natural Law and Libertarian Theory. In J. G. Hülsmann, \& S. Kinsella (Eds.), Property, Freedom \& Society-Essays in Honor of Hans-Hermann Hoppe (pp. 197-210). Auburn, AL: LvMI.

Mack, E. (2008). Individual Rights. In R. Hamowy (Ed.), The Encyclopedia of Liberta-

${ }^{13}$ Chartier does not explain why animals would be exempted by the Nonaggression Maxim (NAM), which, within its system, makes explicit the requirements implicit in the principles of correctness and respect: Chartier, 2013: p. 44. 
rianism (pp. 244-247). Los Angeles, CA: SAGE Publications.

Miller, F. (2008). Natural Law. In R. Hamowy (Ed.), The Encyclopedia of Libertarianism (pp. 351-353). Los Angeles, CA: SAGE Publications.

Mises, L. (1922). Die Gemeinwirtschaft. Jena: Gustav Fischer Verlag.

Murphy, M. (2011). The Natural Law Tradition in Ethics. In E. N. Zalta (Ed.), The Stanford Encyclopedia of Philosophy. Stanford, CA: The Metaphysics Research Lab. https://plato.stanford.edu/archives/win2011/entries/natural-law-ethics

Pallante, F. (2008). Il neoistituzionalismo nel pensiero giuridico contemporaneo. Napoli: Jovene.

Pievatolo, M. C. (2010). Il Gorgia di Platone. https://btfp.sp.unipi.it/dida/gorgia

Rödig, H. J. (1973). Die Theorie des geritlichen Erkenntnisverfahrens. Berlin-Heidelberg: Springer Verlag. https://doi.org/10.1007/978-3-642-65598-2

Rothbard, M. N. ([1957] 2011). In Defense of "Extreme Apriorism". In Economic Controversies (pp. 103-111). Auburn, AL: LvMI.

Rothbard, M. N. ([1978] 2006). For a New Liberty(2nd ed.). Auburn, AL: LvMI.

Rothbard, M. N. ([1982] 1998). The Ethics of Liberty. New York: New York University Press.

Tanzi, A. (2004). Cosa resta dell'istituzionalismo giuridico? L'Ircocervo, 1, 1-26.

Tavormina, V. (2003). Il processo come esecuzione forzata. Napoli: Jovene.

Tavormina, V. (2013). Diritto e processo rivisitati. Jus, 1, 47-107. 